\title{
Different Threads
}

\author{
Tara Watson
}

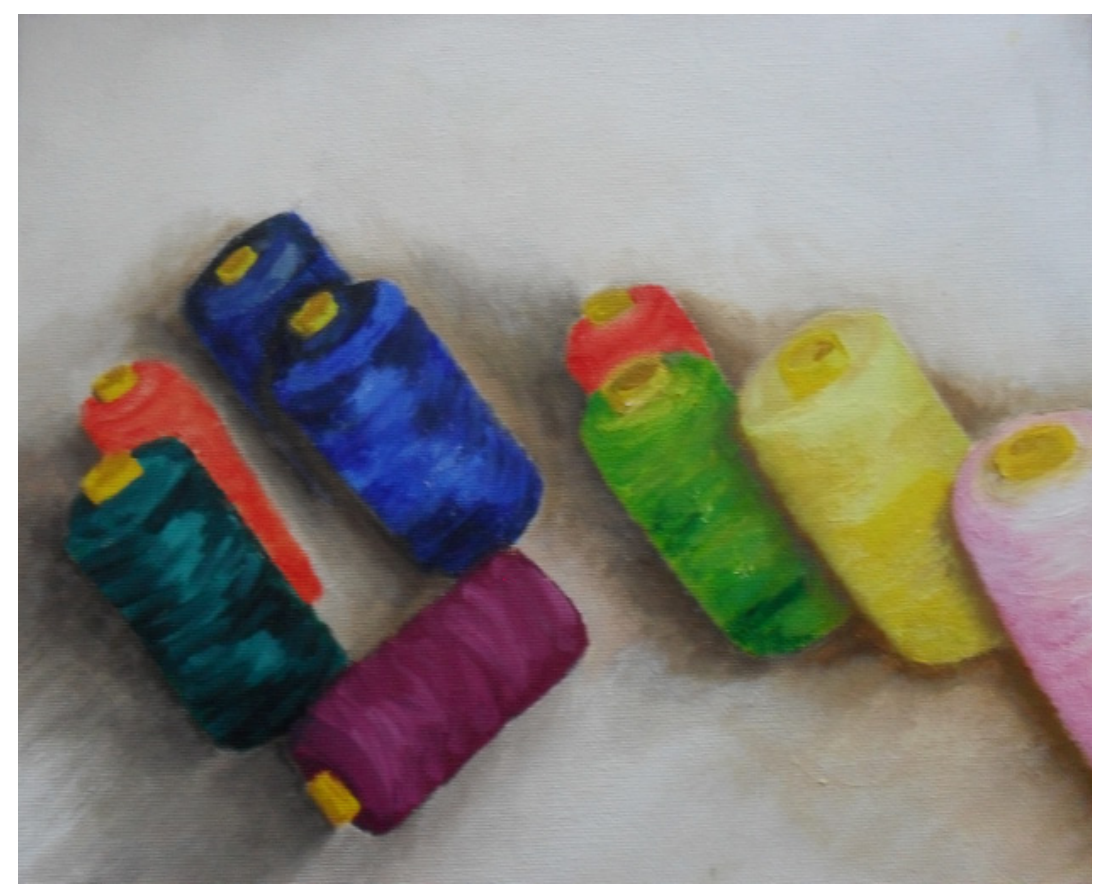

Offset no. 11 | 115 